\title{
Histochemical Studies on the Male Accessory Glands of the Tenebrionid Beetle Blaps polychresta (Coleoptera, Tenebrionidae)
}

\author{
Abdel- Moneim H. El-Zoheiry \\ Zoology Department, Faculty of Science, Alexandria University, Egypt.
}

\begin{abstract}
The aim of the presnt study is to describe the male accessory glands of the tenebrionid beetle Blaps polychresta using histochemical methods and to detect the nature of their secretions. In the adult male tenebrionid beetle Blaps polychresta, there is one pair of bean - shaped and other pair of long tubular accessory reproductive glands. Each bean - shaped gland consists of a single layer of secretory columnar epithelium, surrounded by a muscular coat which is highly tracheated and innervated. Each tubular gland consists of one type of secretory columnar epithelium, surrounded by thin muscular coat which is innervated and highly tracheated. The nuclei of secretory cells in both glands are situated in the basal zone. Histochemical tests of the bean - shaped glands indicate that the secretion of these glands is mainly composed of neutral mucopolysaccharide, glycogen, proteins and lipids. Histochemical tests of the tubular glands indicate the presence of neutral mucopolysaccharide and scanty acidic mucopolysaccharide secretion inside the lumen of these glands, the positive reaction for glycogen and proteins in the cells and secretion inside the lumen of these glands indicate the glycoprotein nature of the secretion.
\end{abstract}

Keywords: Blaps, Bean - shaped, tubular male accessory glands, Histochemistry.

\section{INTRODUCTION}

Male accessory glands are commonly found in insects except for some Apterygota and Diptera (Grimes \& Happ, 1980) and they play several key roles in their reproduction. One of the main functions of these glands is to secrete the substances involved in the production of spermatophores structures that protect the sperms and facilitates their transfer from the male to the female (Leopold, 1976; Muzzi, 2020). Nevertheless, male accessory gland secretions are often involved in many other processes such as the structural organization of spermatozoan bundles (Viscuso et al., 2001) or the promotion of their activation and motility ensuring the successful storage inside the female genital tract (Lung et al., 2001; Mueller et al; 2007). In some other cases, the products of the male accessory glands are directly involved in spermatozoan competition by either inactivating / reducing the effective number of germ cells from the previous mating (Muzzi, 2020). Other subsidiary effects of accessory gland secretions include the ability to directly affect and modulate the post mating behavior of females, causing a vast array of responses that include increasing in egg production and maturation, enhancement of oviposition and decrease in re-mating receptivity (Avila et al; 2011; Hayashi and Takami, 2014; Yu et al; 2014; Yamane et al, 2015; Carmel et al, 2016).

The aim of the present study is to describe the male accessory glands of the tenebrionid beetle Blaps polychresta using histochemical methods and to detect the nature of their secretions.

\section{MATERIALS AND METHODS}

The male adults of Blaps polychresta were collected from gardens during the breeding season (September - November) and reared in the laboratory, Faculty of Science, Alexandria University, under normal conditions.

The bean - shaped and tubular accessory glands were dissected out using a dissecting stereo binocular microscope and fixed in alcoholic Bouin for light microscopy. Paraffin sections (5-7 um thick) were stained using Ehrlich's haematoxylin and eosin. Unfixed cryostat sections (10 um thick) were stained using Sudan III for the demonstration of lipids. For the detection of carbohydrates, they were stained using the PAS-Alcian blue method (Mowry, 1963). For the detection of proteins and glycogen, paraffin sections fixed in $10 \%$ neutral buffered formalin, stained with mercuric bromophenol blue for proteins (Mazia et al., 1953) and Best's Carmine for glycogen (Graumann and Neumann, 1971).

\section{RESULTS AND DISCUSSION}

In an earlier work, El- Zoheiry, (1999 a,b) referred to that the reproductive system of adult male beetle Blaps polychresta consists of two testes, two vasa deferentia, two seminal vesicles, an ejaculatory duct and two pairs of accessory glands, one pair is long and tubular and the other is bean shaped (Fig. 1). The two seminal vesicles and the two pairs of accessory glands open into the proximal end of the ejaculatory duct. The author studied the ultrastructure of accessory glands in Blaps polychresta. Paraffin sections of bean - shaped gland showed secretory columnar epithelium 
surrounded by a muscular coat which is highly tracheated (Fig. 2), and the tubular gland showed also secretory columnar epithelium - with apocrine secretion in the apical part of cytoplasm - and surrounded by a thin muscular coat (Fig. 3).

Histochemical tests of bean - shaped gland showed that both the secretion inside the lumen of the gland and the cells reveal strong reaction (blue colour) with mercuric bromophenol blue indicating the presence of proteins (Fig. 4). Paraffin sections of the same gland stained with PAS - Alcian blue showed pink secretion inside the lumen of the gland and in the apical parts of their secretory cells indicating the presence of neutral mucopolysaccharides (Fig. 5). Moderate positive reaction for glycogen is shown in the basal parts of the cells of bean - shaped gland, positive reaction for glycogen is also shown inside the lumen of the gland (Fig. 6). Unfixed cryostat sections of bean shaped gland showed positive reaction when stained with Sudan III indicating the presence of lipids (Fig. 7). Histochemical tests of tubular gland of Blaps polychresta give negative reaction for lipids which are strongly detected in the paragonadal fat body surrounding the gland with faint blue secretion inside the lumen of this gland (Fig. 8). Protein is detected in both the secretions and the cells of this gland (Fig. 9). Neutral mucopolysaccharide is detected in the secretory cells and scanty acidic mucopolysaccharide is detected inside the lumen of the tubular gland (Fig. 10). Strong reaction with Best's carmine in both the secretion inside the lumen of gland and the cells is shown indicating the presence of glycogen (Fig. 11). In the mucoid glands, the staining affinity for Best's carmine is very strong (Graumann \& Neumann, 1971). This fact agrees with the obtained results in Blaps polychresta. The present observations in Blaps polychresta coincide with the conclusion of Mowry (1963) who stated that the Alcian blue - PAS method stains the neutral mucopolysaccharides red and the acidic mucopolysaccharides blue.

It is suggested that some precursor material, or even prefabricated molecules from the paragonadal fat body - which is considered as an important center of intermediary metabolism - may enter the accessory glands for further elaboration into the characteristic secretions of the accessory glands. This seems rather unlikely, however, since fat body cells are dominated by glycogen and netural lipid deposits in contrast to the non glycogen polysaccharide and acidic lipid normally found in accessory glands (Odhiambo, 1967; c.f., Odhiambo, 1969). Leopold (1976) reported that proteins and carbohydrates appear to be ubiquitous components of accessory reproductive glands of Orthoptera, Dictyoptera, Hemiptera, Coleoptera, Lepidoptera and Diptera. Gadzama et al. (1977) showed that proteins and glycoproteins are detected in secretion of the tubular gland of Tenebrio. Chen (1978) reported that proteins are more concerned with the transfer and utilization of the sperm rather than the stimulation of fecundity. In Drosophila, the sperm may have the capacity to utilize amino acids for energy production.

It is concluded that these studies have confirmed and agreed with most histological, ultrastructural and histochemical observations in similar glands in other species. This knowledge of male accessory gland ultrastructure and nature of their secretory product should facilitate the elucidation and gives the interpretation for the function of these important organs in the reproductive behaviour of these insects.
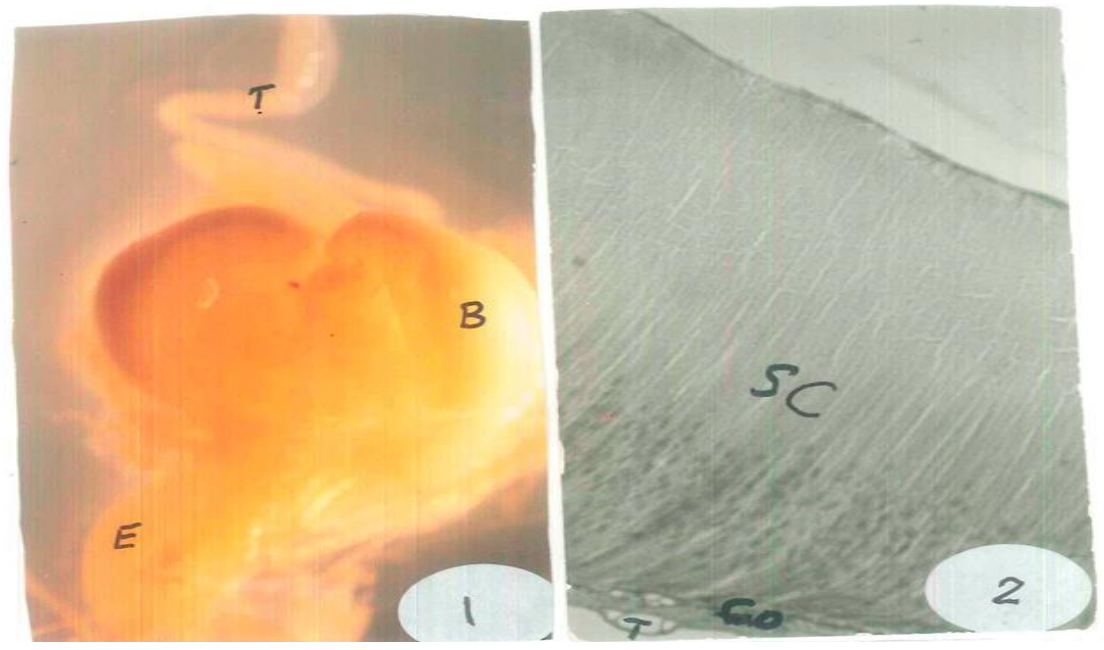

Fig. 1: Showing the bean - shaped accessory gland (B), tubular gland (T) and ejaculatory duct (E)of male Blaps polychresta. X10

Fig. 2: Paraffin section of the bean- shaped gland showing secretory columnar epithelium (SC), muscular coat $(C O)$ and trachea $(T) . X 500$ 


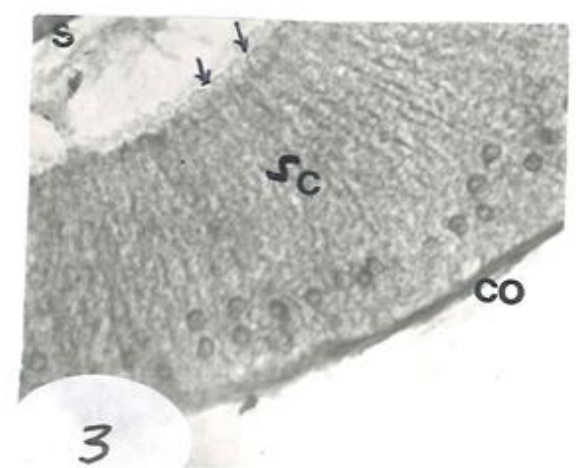

Fig. 3: Paraffin section of the tubular gland showing secretory columnar epithelium (SC) with apocrine secretion (arrows) in the apical part of cytoplasm, muscular coat (Co) and secretory product inside the lumen of the gland (S). $X \mathbf{5 0 0}$

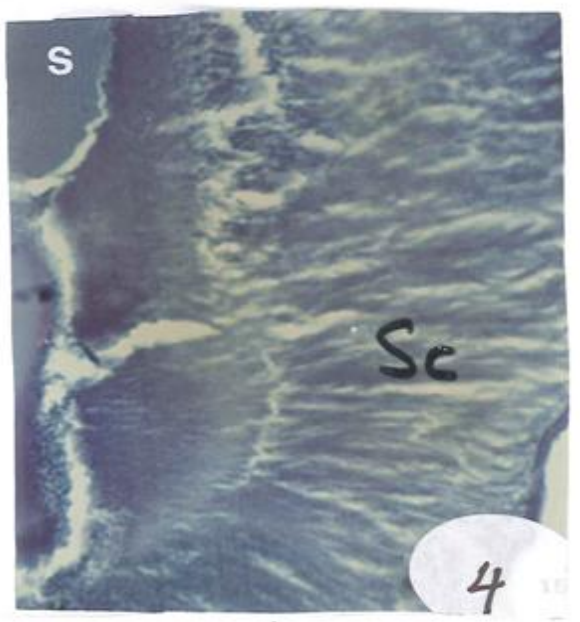

Fig. 4: Paraffin section of bean - shaped gland showing that both the secretion inside the lumen of the gland (s) and the secretory cells (SC) reveal strong reaction (blue colour) with mercuric bromophenol blue indicating the presence of proteins. X 190

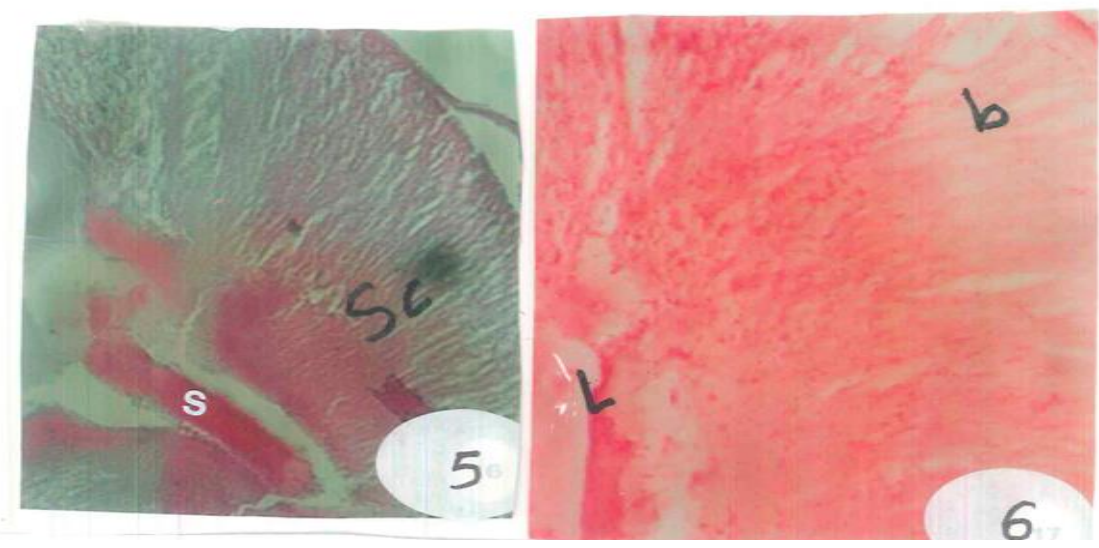

Fig. 5: Paraffin section of bean - shaped gland stained with PAS- Alcian blue showing pink secretion (s) inside the lumen of the gland and in the apical parts of the secretory cells(SC) indicating the presence of neutral mucopolysaccharides. X 190

Fig. 6: Paraffin section of bean - shaped gland stained with Best's carmine showing moderate positive reaction for glycogen in basal parts of the cells $(b)$ which are faintly stained and positive reaction for glycogen is also shown inside the lumen $(L)$ of the gland (red colour). X 190 


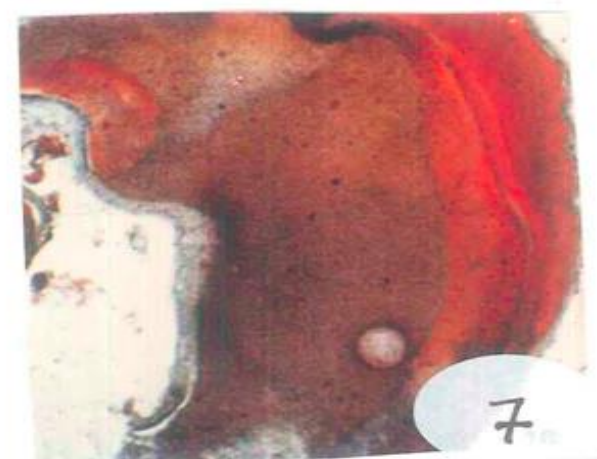

Fig. 7: Unfixed cryostat section of bean - shaped gland showed positive reaction when stained with Sudan III indicating the presence of lipids. X 30

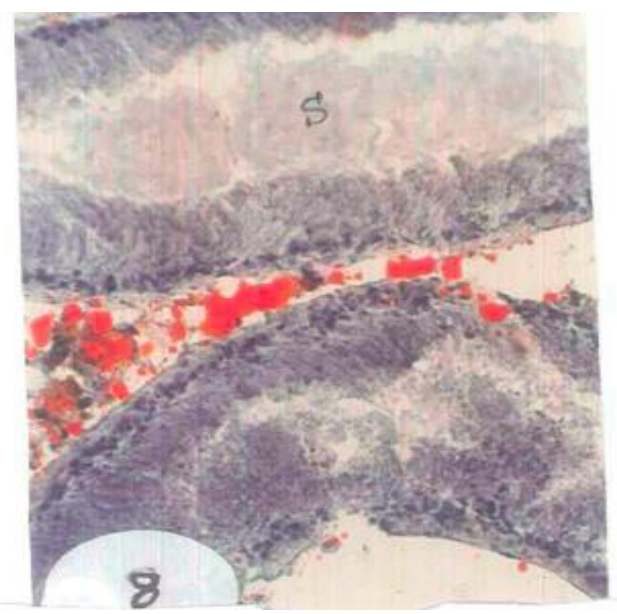

Fig. 8: Unfixed cryostat section of the tubular gland stained with Sudan III showing negative reaction for lipids which are strongly detected in the paragondal fat body surrounging the gland (orange colour) with faint blue secretion (S) inside the lumen of the gland. $X 120$

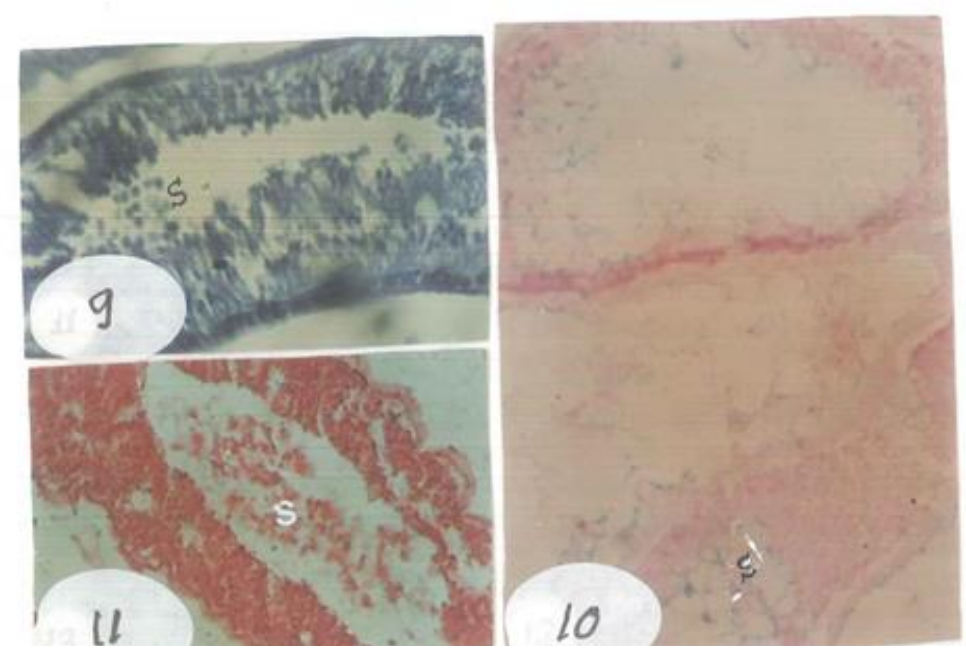

Fig. 9: Paraffin section of tubular gland showing that both the secretion inside the lumen of the gland (s) and the cells reveal strong reaction (blue colour) with mercuric bromophenol blue indicating the presence of proteins. $X 190$

Fig. 10: Paraffin section of tubular gland stained with PAS- Alcian blue showing neutral mucopolysaccharide (pink colour) in secretory cells and scanty acidic mucopolysaccharide secretion inside the lumen of the gland (blue colour). $X 120$

Fig. 11: Paraffin section of tubular gland showing strong reaction (red colour) with Best's carmine in both the secretion inside the lumen of the gland $(S)$ and the cells indicating the presence of glycogen. X 190 


\section{REFERENCES}

Avila, F.W.; Sirot, L.K.; La Flamme, B.A.; Rubinstein, C.D. \& Wolfner, M.F. (2011): Insect seminal fluid proteins: Identification and function. Ann. Rev. Entomol., 56: 21 - 40.

Carmel, I.; Tram, U. \& Herfetz. Y. (2016): Mating induces developmental changes in the insect female reproductive tract. Curr. Opin. Insect Sci. 13: $106-113$.

Chen, P.S. (1978): Activation of protein synthesis in the male accessory glands. In: Biochemistry of Insects. M. Rockstein, ed. Academic Press, Inc. N.Y.pp. $174-181$.

El- Zoheiry, A. H. (1999a): Histological Studies on the bean - shaped accessory glands in the male beetle Blaps polychresta. J. Egypt. Ger Soc. Zool. 28 (C): $241-258$.

El- Zoheiry, A. H. (1999b): Histological studies on the tubular accessory glands in the male beetle Blaps polychresta. J. Egypt. Ger Soc. Zool. 28 (C): $259-274$.

Gadzama, N.M.; Happ, C.M. \& Happ G.M. (1977): Cytodifferentiation in the accessory glands of Tenebrio molitor I. Ultrastructure of the tubular gland in the post-ecdysial adult male. J. Exp. Zool. 200: $211-221$.

Graumann, W. \& Neumann, K. (1971): Handbuch der Histochemie. Band II. Teil 3. Gustav Fischer Verlag, Stuttgart.

Grimes, M. J. \& Happ, G. M. (1980): Fine structure of the bean - shaped accessory gland in the male pupa of Tenebrio molitor (Col., Teneb.). J. Insect Morphol. Embryol. 9: 280 - 296.

Hayashi, N. \& Takami, Y. (2014): Inhibition of female mating by male accessory gland substances in the ground beetle Lepto -carabus procerulus. Physiol. Entomol. 39: $12-18$.
Leopold, R.A. (1976): The role of male accessory glands in insect reproduction. Ann. Rev. Entomol. 21: 199 - 221 .

Lung, O., Kuo, I. \& Wolfner, M. F. (2001): Drosophila males transfer antibacterial proteins from their accessory gland and ejaculatory duct to their males. J. Insect physiol. 42: $617-622$.

Mazia, D.; Brewer, P. A. \& Alfert, M. (1953): The cytochemical staining and measurement of protein with mercuric bromophenol blue. Biol. Bull., 104: $57-67$.

Mowry, R. W. (1963): The use of Alcian blue \& Gx and their combinations with periodic AcidSchiff reaction. Ann. N.Y. Acad. Sc. 106: $402-$ 423.

Mueller, J. I; Page, J. I. \& Wolfner, M. F. (2007): An ectopic expression screen reveals the protective and toxic effects of Drosophila seminal fluid proteins. Genetics, 175: 777 783.

Muzzi, M. (2020): The male reproduction accessory glands of the blister beetles. Science: Article, pii, Published by Elsevier Ltd.

Odhiambo, T. R. (1969): The architecture of the accessory reproductive glands of the male desert locust. I. Types of glands and their secretions. Tissue \& cell. 1: 155 - 182.

Viscuso, R.; Narcisi, L.; Sottile, L. \& Brundo, M. V. (2001): Role of male accessory glands in spermatodesm reorganization in Orthoptera, Tettigonioidea. Tissue \& Cell. 33: 33 - 39.

Yamane, T.; Goenaga, J. ; Ronn, J. L. \& Arnqvist, G. (2015): Male seminal fluid substances affect sperm competition success and female reproductive behaviour in a seed beetle. Pols one. 10, Article e 0123770.

Yu, J. E; Li, C.; Xu, J.; Liu, J. H \& Ye, H. (2014): Male accessory gland secretions modulate female post-mating behaviour in the moth Spodoptera litura. J. Insect Behavior. 27: 105 116. 


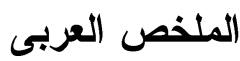

\section{دراسات هستوكيميائية على الغدد الزائدة فى ذكر خنفساء البلابس بولى كريستا (رتبة غمدية الاجنحة - عائلة تنبريونيدي)

الغرض من هذه الدراسات هو وصف الغدد التاسلية الزائدة في ذكر خنفساء البلابس بولي كريســا باســتخدام الطرق الهستوكيميائية بالاضافة الي معرفة طبيعة هذه الافرازات في هذه الغدد. يوجد زوج من الغدد الكلوية الزائدة

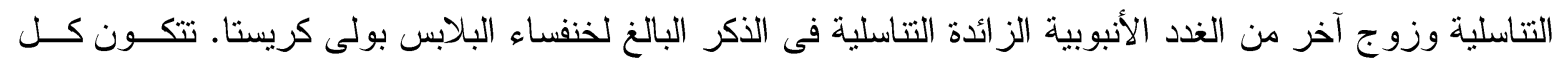

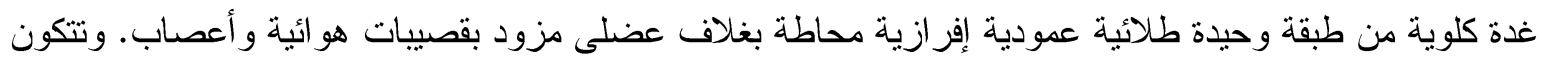

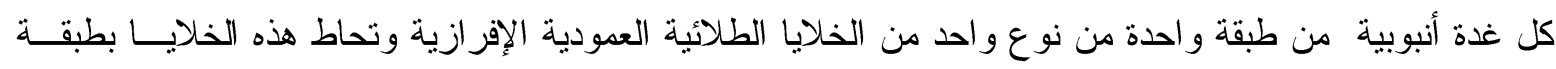

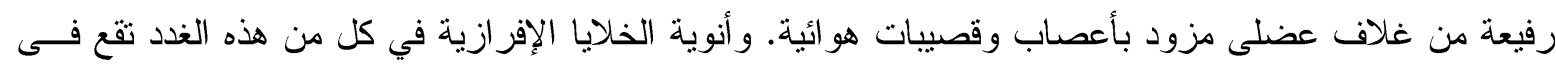
المنطقة القاعدية.

ولقد أوضحت الإختبارات الهستوكيميائية للغدد الكلوية أن إفرازات هذه الغدد تتكون أساساً من سكريات عديــدة مخاطية متعادلة وجليكو جين وبروتينات ودهون.

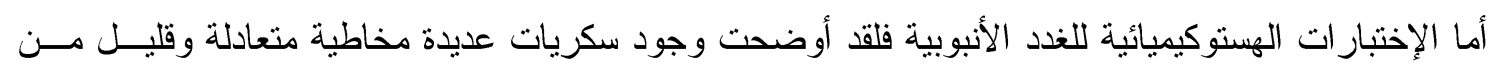

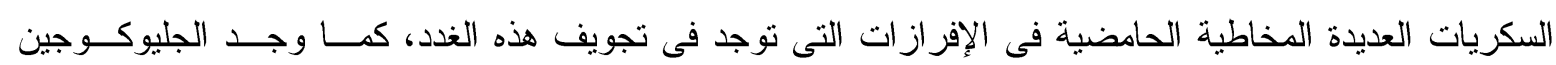
و البروتينات داخل الخلايا وفى الإفرازات التى توجد فى تجويف هذه الغدد مما يوضح الطبيعة البروتينية الســكرية لهذه الإفراز ات. 